\title{
Information and Communication Technology and Administration of 2015 General Election in Nigeria
}

\author{
Dr. Ejikeme Jombo Nwagwu \\ Lecturer, Department of Political Science, University of Nigeria, Nsukka \\ Email: ejikeme.nwagwu@unn.edu.ng
}

\section{Doi:10.5901/mjss.2016.v7n4p}

\section{Abstract}

The organization and conduct of free, fair and credible elections had been a perennial problem facing Nigeria since her independence. Political instability, electoral malpractices, post-election violence, arson, killing of political opponents and litigations characterized the polity. Information and communication technology was introduced in election administration in Nigeria to curb excessive electoral fraud to the barest minimum and foster credible elections. A survey research design was adopted to elicit information from the electorates on the performance of INEC in administering the 2015 general elections using biometric card reader and the customized permanent voter card, to ascertain whether the technological devices minimized electoral malpractices and enthroned free, fair, and credible elections in Nigeria. The study also established the challenges INEC faced in administering the elections. The instrument used to glean information from the respondents was questionnaire. Qualitative method of data collection was also used to elicit data from documentary evidence of secondary sources. Quantitative method of analysis was employed. The results of the study revealed that introduction of ICT in administration of 2015 elections in Nigeria minimized electoral fraud; and the result also showed that INEC faced numerous challenges in the elections. The study recommends future use of ICT in election administration in Nigeria to foster systemic stability and political development.

Keywords: Information, Communication, Technology, Election, Administration

\section{Introduction}

Nigeria have had turbulent elections from 1922 to 2011. It had battled with perennial problems associated with inability to organize and conduct free, fair and credible elections since her nationhood in 1960. All past elections in the post-colonial Nigeria were characterized by irregularities, ranging from imposition of unsalable candidates at party primaries, intraparty contradictions and suffocation of democracy, political manouevres, and ungodly manipulations and mutilation of election results amongst the political class, disenfranchisement of eligible voters, thuggery and rigging, snatching of ballot boxes, multiple registration of voters, multiple voting, killing or maiming of political opponents to intimidate supporters, under-aged voting, buying of voters' cards for unregulated and unsupervised voting, hiring of machinery voters from neighbouring countries, to post-election litigations (it had been a struggle of survival of the fittest). Nigeria had experienced post-election violence in South-West in 1965, 1983 and 2003; North-East, North-West and North-Central in 1965, 2011, which claimed over 5000 lives and destruction of properties. Party supporters clashed severally with opponent groups at various locations in one election or the other, and over 3000 people were reported to have been killed. For 16 years since the return of democracy in 1999, elections have been won by hook or crook. The consequences of political instability and politically related crisis have been rampant declaration of state of emergencies, imposition of curfews, high security challenges, incessant military take-over of governments, threats of sedition and secession such as the declaration of sovereign state of Biafra in 1967 by Eastern Nigeria and the bloody 30 months Nigeria/Biafra civil war. The January 1966 military coup and counter coup of July 1966 and a follow-up pogrom meted out against the Eastern Nigeria origins were the consequences of political instability (Nwagwu, 2011). The incessant political violence and the crisis ridden nature of elections in Nigeria gave patriotic citizens, Nigerians in diaspora, international bodies, comity of nations and external stakeholders in Nigeria project serious concern as to the fate of the nation in 2015 elections. Ban Ki-Moon, the United Nation Secretary-General also expressed worry over the aftermath of the elections, and sued for absolute peace and tranquility before, during and after the elections. To avert the impending crisis, the two key players in PDP and APC (party flag-bearers) were compelled to enter into peace treaty - to maintain absolute peace before, during and after the 2015 elections.

To curtail these electoral vices and stem the adverse effects of these monstrous indicators on the nation's 
socio-economic and political development efforts, a new political paradigm, to information and communication technology (ICT) was first introduced by Independent National Electoral Commission (INEC) in 2003 to register eligible voters and compile credible voters register with a view to consolidating the nascent democracy. The usage of ICT in election management was considered critical as it was expected to eliminate the incidents of multiple registration, which had been one of the main political tools for rigging elections by unscrupulous and savage elements. This unique technique was employed to capture mass involvement in governance and empowerment of the teeming electorates to participate in electoral processes. The innovation was adjudged core strategic imperative, which was meant to showcase governance in Nigeria with the fundamental challenge to excel. INEC sustained the tempo of the achievements recorded in previous exercise by reintroducing ICT mechanism in 2007 elections in updating the voters register, as Nigerians were poised to witness a transitional process from civilian President to another for the first time. In stressing the importance of ICT in the management and conduct of elections, Jega (2012) notes that:

\begin{abstract}
election management bodies around the world have employed a number of innovative approaches, some of which are now considered best practice, to improve the management and conduct of elections. Electoral reforms that have been instituted include the use of information and communication technology, adoption of more transparent and inclusive processes, professionalization of the organization, amendments to legal framework and improvement of relationships with external stakeholders. As a result of these efforts, the past several years have seen the varying successes of a number of election management bodies in the manner by which they prepare, organize, administer and conduct elections (Jega, 2012).
\end{abstract}

The INEC Chairman, Professor Maurice Iwu began sensitization of the public on the various models intended to be employed in 2007 general elections. These concepts included the Option A4, Electronic Voting (e-voting) and Open Secret ballot system. The Option A4 (a model invented by the National Electoral Commission (NEC) (as it was known then) in 1993 presidential election, whereby voters were expected to queue behind the representative of a given political party or its candidate and counting would be executed before the public). This was introduced to minimize rigging. The model (option A4) recorded success as 1993 presidential election was adjudged free, fair and credible by local and international observers. Ironically, the military scuttled the final results and annulled the election.

The e-voting embraced varying types of voting, which entails electronic means of casting votes and counting same. It involved punch-cards optical scan voting systems and specialized voting kiosks, also known as self-contained direct recording electronic. The e-voting mechanism involves transmission of ballots and votes via telephones, private computer networks or even the internet with the merits of speeding up the counting of ballot papers and as well enhancing voting access for physically challenged persons and reducing electoral malpractices to its barest minimal. This novel and sophisticated concept was suddenly shelved in 2007 election, due to technophobia, as INEC succumbed to pressure, and open secret ballot system was adopted (Nweke, 2008).

Since the return of democracy in 1999, politics favoured PDP in suspicious manner. It won elections by hook or crook with wide margins. In February 1999, the party's flag bearer, Chief Olusegun Obasanjo with Alhaji Abubakar Atiku (running mate), won the presidential election with 62.6 percent. In the legislative election held on $12^{\text {th }}$ April, 2003, PDP secured 54.5\% - 223 seats out of 360 seats in the House of Representatives; and 76 seats out of 109 in the Senate. The party flag bearer for $19^{\text {th }}$ April, 2003 presidential election, Chief Olusegun Obasanjo, was re-elected with $61.9 \%$. The security agents were alleged to have been used to rig elections. In April 2007 elections, Alhaji Umaru Musa Yar'Adua, the presidential candidate for PDP was declared the winner amid widespread allegations of unprecedented electoral fraud. Although the election was adjudged free and fair by local and international observers, but its credibility was not highlighted. In National Assembly election, the party won 260 seats out of 360 in the House of Representatives; and 85 seats out of 109 in the Senate. The then out-going President tagged the 2007 presidential election "a do or die" outing. Dr. Goodluck Jonathan, the Vice-President, succeeded President Umaru Musa Yar'Adua at the demise of the later in 2010 after protracted illness. In 2011 elections, President Goodluck Jonathan won with over 22 million votes or 58.89\%, while the rival, Muhammadu Buhari, secured 12.8 million votes or $43.67 \%$. The PDP victory, amid cry of fraud, was in clear majority with 208 lawmakers in the House of Representatives and 58 seats in the Senate (Onabanjo, 2015).

The role of ICT in elections is to ensure secrecy of votes, and to accurately and credibly determine the will of the people and to sustain participatory democracy. For ICT to play its vital functional roles creditably, effectively and efficiently, all technological devices in election administration should serve to enhance the cardinal principle of accuracy, accessibility, transparency and informed electorates. Therefore, the need for the electorates to be sufficiently enlightened on the primary roles of ICT in election processes ought to be stressed elaborately. Considering the volume of financial and material involvement in elections, the management and conduct of elections are serious business in democratic governance. Jega (2012) notes that: 
the conduct of elections is one of the largest, most costly, most administratively and logistically burdensome operations at a national level that a single country could ever undertake in times of peace. It involves a complex and large-scale set of operations, spanning a multitude of activities including delivery of professional training to thousands of electoral officers and ad hoc or temporary poll workers, designing and delivering voter education, registering voters, regulation of political parties, monitoring political party campaigns, procurement of hundreds of election materials in enormous quantities, developing voting and counting procedures, liaising with stakeholders, dealing with security, and adjudicating electoral disputes (Jega, 2012).

The objective of this study, therefore, is to investigate the roles ICT played in the administration of 2015 elections; to ascertain whether the application of Direct Data Capturing machine for revalidation of voters register, smart card readers for accreditation of eligible voters, and the customized permanent voters card minimized election malpractices and guaranteed free, fair and credible 2015 elections in Nigeria. The study also investigated the challenges INEC encountered in electronic-administration of the elections.

Election is the major ingredient of democracy because there is no true democracy without elections. One function of elections is to provide a competitive platform for public offices and a credible means of holding the government responsible to the electorates. Competitive elections facilitate choice, dialogue, accountability, transparency and legitimacy (Hague and Harrop, 2010). Election empowers the people to make choice of who they want to govern them within a timeframe. Therefore, election means recruitment of the representatives by the choice of the voters. Democracy involves the concept of competition for leadership. Democracy seems to imply a recognized method by which to conduct the competitive struggle, and that the electoral method is practically the only one available for communities of any size (Johari, 2009). Some scholars have portrayed elections as the very heart of democracy, while democracy is portrayed as an institutional arrangement, as a means of filling public offices by a competitive struggle for the people's vote. Election in a democratic process guarantees the people the opportunity of assessing the individual's credibility, capability and accepting or refusing the men who are to rule them. Therefore, election is a device for filling an office or post through choices made by a designated body of people called the electorate. Election is seen as a decision making process where a population chooses individual(s) to hold official position(s) on trust (Heywood, 2002; Nweke, 2008).

\section{Overview of 2007 General Elections}

In preparation for the 2007 election, INEC employed ICT into core electoral process. It was recorded that 13,000 integrated data capture systems were deployed by INEC in 2006 voters registration exercise; 22,000 Direct Data Capturing (DDC) machines, and 18,000 devices for revalidation of voters register for electorates who would be eligible on or before $13^{\text {th }}$ February, 2007, thereby giving enough room for the registration of over 61 million voters with 40,000 DDCs on the whole (with data and the printer units accessories) at the end of the exercise. INEC explained that the adoption of DDC technology with manual back-up for the revalidation of voters' register in the 36 states and the federal capital territory, Abuja against the Optical Mark Reading system was to make the exercise more transparent, speedy and less cumbersome.

In spite of the robust technological arrangements, open secret ballot system was finally adopted for the exercise due to presidential influence and pressure. 2007 election was truly a monument of fraud, where rigging was approved norm as it had been the practice in the past election exercises. Candidates of opposition parties who won gubernatorial elections in some states were shortchanged by INEC and PDP. The result was that candidates of PDP who failed in the election were declared winners by INEC. Some candidates within the ruling party who won their party primaries were also shortchanged and unsalable candidates were imposed on the electorates by political godfathers. Most of the aggrieved sought redress in election tribunals and courts of law to reclaim their mandate. Some of the cases are illustrated hereunder.

Table 1: Cases Of Fraudulent Declaration of 2007 Governorship Election Results

\begin{tabular}{|l|l|l|}
\hline State & Contestants/Events & Verdict of the Election Tribunals \\
\hline Edo & $\begin{array}{l}\text { Adams Oshiomhole of ACN vs. Oserheimen Osunbor of PDP. } \\
\text { Osunbor was declared the winner, while Oshiomhole petitioned to } \\
\text { Election Tribunal to challenge the declaration. }\end{array}$ & $\begin{array}{l}\text { Adams Oshiomhole of ACN was declared the } \\
\text { rightful winner. The Tribunal ordered that the } \\
\text { candidate be sworn in as the duly elected Governor. }\end{array}$ \\
\hline Ondo & $\begin{array}{l}\text { Segun Mimiko of Labour Party vs. Segun Agagu of PDP. Segun } \\
\text { Agagu, incumbent Governor, was declared the winner, while Mimiko } \\
\text { went to Election Tribunal to challenge the declaration. }\end{array}$ & $\begin{array}{l}\text { Segun Mimiko of Labour Party was declared the } \\
\text { rightful winner. The Tribunal ordered that the } \\
\text { candidate be sworn in as the duly elected Governor. }\end{array}$ \\
\hline
\end{tabular}




\begin{tabular}{|l|l|l|}
\hline Ekiti & $\begin{array}{l}\text { Kayode Fayemi of ACN vs. Segun Oni of PDP. Segun Oni was } \\
\text { declared the winner, while Kayode Fayemi went to Election Tribunal } \\
\text { to challenge the declaration. }\end{array}$ & $\begin{array}{l}\text { Kayode Fayemi of ACN won the legal battle. The } \\
\text { Election Tribunal ordered that Fayemi be sworn in as } \\
\text { the duly elected Governor. }\end{array}$ \\
\hline Osun & $\begin{array}{l}\text { The incumbent Governor, Olagunsoye Oyinlola (PDP) vs. Engr. Rauf } \\
\text { Aregbesola (ACN). Oyinlola was declared the winner, while } \\
\text { Aregbesola went to Election Tribunal to challenge the declaration. }\end{array}$ & $\begin{array}{l}\text { Engr. Rauf Aregbesola of ACN won the legal battle. } \\
\text { The Election Tribunal ordered that Aregbesola be } \\
\text { sworn in as the duly elected Governor. }\end{array}$ \\
\hline Anambra & $\begin{array}{l}\text { Chris Ngige of PDP vs. Peter Obi of All Peoples Grand Alliance. } \\
\text { Ngige was declared the winner, while Obi went to court to challenge } \\
\text { the declaration. Obi lost the battle at the lower court but he appealed } \\
\text { to the higher court. }\end{array}$ & $\begin{array}{l}\text { The Court of Appeal declared Peter Obi of APGA the } \\
\text { rightful winner and ordered that the candidate be } \\
\text { sworn in as the duly elected Governor. }\end{array}$ \\
\hline Delta & $\begin{array}{l}\text { Great Ogboru (ACN) vs. Emmanuel Uduaghan (PDP). Uduaghan was } \\
\text { declared the winner, Ogboru petitioned to Election Tribunal to seek } \\
\text { redress. It was observed that both parties massively rigged with } \\
\text { obvious indicators of electoral malpractices. }\end{array}$ & $\begin{array}{l}\text { The Election Tribunal cancelled the entire exercise } \\
\text { and mandated INEC to conduct fresh election for the } \\
\text { state within 9 months from the date of the judgment. } \\
\text { Uduaghan of PDP won in the run-off. }\end{array}$ \\
\hline
\end{tabular}

Source: Nwagwu, E.J. (2011). Elections and Party Politics in Nigeria: Lesson After 50 years. Nigeria at Fifty: Issues, Challenges and Agenda, Vol. 2. Enugu: Timex Enterprises.

Table 2: Cases of Fraudulent Declaration of 2007 Party Primary Election Results

\begin{tabular}{|l|l|l|}
\hline State & Contestants/Events & Verdict of the Supreme Court of Appeal \\
\hline Rivers & $\begin{array}{l}\text { Rotimi Amaechi vs. Celestine Omehia (both PDP). Amaechi } \\
\text { won the party primary in Rivers State, but Omehia was imposed } \\
\text { on the State by the PDP godfathers. Thereafter, Omehia } \\
\text { contested the election and won. He was sworn in. Amaechi went } \\
\text { to court to seek redress.. }\end{array}$ & $\begin{array}{l}\text { Amaechi lost the first battle at the lower court. The Supreme } \\
\text { Court of Appeal declared Amaechi the rightful flag-bearer } \\
\text { for PDP in Rivers State having been duly elected at the } \\
\text { party primary. The Court also declared him the winner of } \\
\text { the election. Amaechi was sworn in accordingly. }\end{array}$ \\
\hline Imo & $\begin{array}{l}\text { Ifeanyi Araraume vs. Charles Ugwuh (both PDP). Araraume won } \\
\text { the 2007 PDP party primary in Imo State, but Ugwuh was } \\
\text { imposed on the State by PDP godfathers. Araraume went to } \\
\text { court to challenge the imposition. }\end{array}$ & $\begin{array}{l}\text { The Court of Appeal ruled in favour of Araraume. In protest, } \\
\text { PDP withdrew its support and dissociated the party from } \\
\text { Araraume's candidature. The candidate lost. }\end{array}$ \\
\hline
\end{tabular}

Source: Nwagwu, E.J. (2011). Elections and Party Politics in Nigeria: Lesson After 50 years. Nigeria at Fifty: Issues, Challenges and Agenda, Vol. 2. Enugu: Timex Enterprises.

Political instability and suffocation of democracy in party politics are bane to national cum political development. Developmental challenges facing Nigeria are grossly complex and multiple. The challenges of Nigeria's corporate existence are being compounded by the failure or apparent negligence of the political leadership to squarely address certain elementary aspects of the electoral procedures, but quite disturbing issues in our democratic processes. Lust for power, excessive wealth accumulation and ethnic chauvinism have derailed the senses of our political leaders and channeled their purposeless focus to parochial and primordial social issues like tribe, religion, ethnicity, culture, godfatherism and personal ego. Ethnic groups perceive other rival groups as serious threat to their survival as a people. Rigging of election is one of the methods of securing political relevance, and transferring power to godsons who, in turn, would be used as tool to siphon state treasury for personal aggrandizement. This unhealthy competition for scarce resources and massive rigging in elections lead to intractable conflicts among the competing ethnic nations which has resulted in post-election deaths. Iwu (2009) observes that:

here is a system in which individuals primitively acquired such enormity of resources that embolden them to challenge the state and become laws into themselves with their own army and all; a system in which political parties brazenly deny their members who won primaries the ticket they won and allocate same to others for one reason or another; a system in which some individuals solely pick candidates for a political party in an election; a setting in which majority of the political aspirants do not believe there is any benefit in campaigning and convincing the electorates, but that with money and massive arsenal of coercion the electorates will be subdued; an environment in which politicians are perpetually bidding to buy electoral officers, often at sums of money that could transform a whole town; a system in which the very law guiding elections are not known until few months to the elections - this is the environment of Nigeria's electoral democracy from where elections without flaws are expected (Iwu, 2009 cited in Nwagwu, 2011).

Tables 1 and 2 above reflect the level of political underdevelopment of Nigeria. A country where everyone does 
with impunity whatever he or she wants without recourse to the rule of law. This is a nation where some elements are above the law of the land. How can the society curb the excesses of these lawless individuals and subject all citizens to the same law governing the conduct and behaviour of civilized people? There is need for reorientation and reformation of the psychic of political class in our struggle for political development and civil behaviour. Iwu (2009) cited in Nwagwu (2011) argues that "the actual issue of the moment as some continue to cast it, is not reform of the electoral process in isolation. He stressed that the relevance of the reform exercise notwithstanding, there is an urgent need for a comprehensive reform that would at once encompass the intertwined spheres of politics and economics. The reform that beckons to Nigeria is that which would address, among other things, the access to money by individuals and the limit to which that can be used in the realm of politics; exposure of the majority within the society to exploitation, abuse and denial of their basic rights by those who cornered their common wealth in the first place, citizen rights and opportunity available to every citizen to aspire and attain position of prominence whether in politics, the professionals of the private sector or public service, based primarily on talent and ability and not on the size of the pocket, but obedience to rule of law by all citizens and groups and how best to enforce the pre-eminence of the laws of the land".

\section{2011 Elections and Electoral Reform}

The 2011 elections were adjudged by both local and international observers to be free, fair and credible. Indeed, the conduct of the elections has halted, if not reversed the history of progressive degeneration of the outcome of elections in Nigeria from 1922 to 2007. The post- election bloody violence truncated the success of the exercise. Howbeit, Late Alhaji Umaru Musa Yar'Adua, the winner of 2007 presidential election under the platform of PDP, acknowledged that the electoral procedures in Nigeria were below international standard and unacceptable in the $21^{\text {st }}$ century. Electoral Reform Committee was constituted to overhaul the entire electoral processes and review the subsisting electoral law to conform with world standard. President Goodluck Jonathan consolidated the dream of his predecessor, and strengthened the task of that Committee to deliver Nigeria from the demonic grip.

In April 2011 presidential election, PDP secured 22,495,187 votes (58.89\%), while the Congress of Progressive Change garnered $12,214,853$ votes (31.98\%). The pronouncement of PDP candidate as the winner charged and ignited the already overheated atmosphere in Northern axis. Post-election violence simultaneously ensued as Muslim supporters of CPC unruly attacked perceived "enemies" and it was reported that over 300 people died, including youth coppers who served INEC in the exercise as ad hoc staff. The loser of that election seriously fanned the crisis with incisive and provocative utterances that spurred the Muslim youths to unguarded destructive actions (Ocholi, 2015). The ugly incidents and post-crises utterances and body language of some Muslims put Nigerians, particularly the Southern people on their toes about what was going to be the aftermath of 2015 presidential election. Hence the pre-election exodus of southerners from the north, thereby forfeiting their voting rights in the areas where they registered for the elections.

The voters turnout for the 2011 presidential election in the six geo-political zones was impressive as North-West recorded 56\%, North-East (56\%), North-Central (49\%), South-West (32\%), South-East (63\%), and South-South (62\%). The overall national turnout was (52\%) as illustrated in figure 1 below. Voters turnout in South-East was the highest in the presidential election, while South-West recorded the lowest turnout which depicted political apathy.

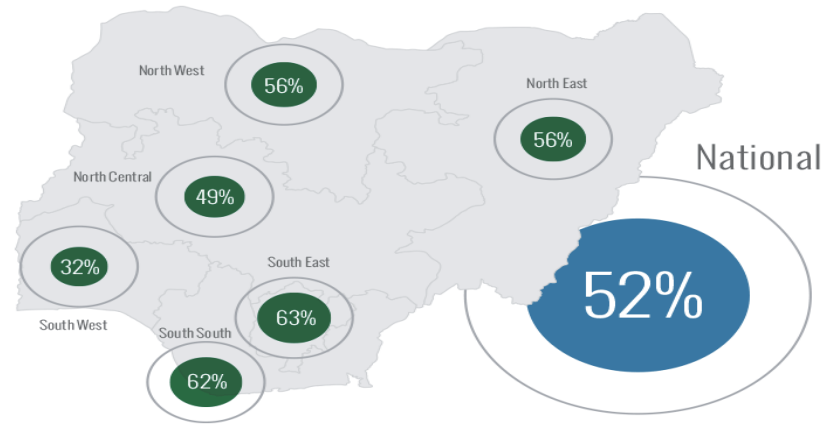

Figure 1: Breakdown of 2011 Presidential Voters Turnout by Zone

Source: Independent National Electoral Commission (INEC). 


\section{Intra-Party Conflicts and Political Contradictions}

The decline in the PDP's electoral value in the National Assembly began with the formation of a stronger opposition party - All Progressive Congress (APC), a coalition of hitherto four feeble parties - Action Congress of Nigeria, Congress for Progressive Change, All Nigeria Peoples Party, and a faction of All Progressive Grand Alliance. Muhammadu Buhari emerged the party flag-bearer. Besides, the exit of Chief Olusegun Obasanjo from PDP (the former national leader of the party and former Chairman of the Party's Board of Trustee); the defection of seven PDP Governors to APC; the defection of Aminu Waziri Tambuwal, the PDP-Speaker, House of Representatives to APC; and defection of 37 other PDP members of the House to APC further weakened the political hegemony of PDP in the National Assembly. The number of PDP governors dropped from 27 in 2009 to 20 before $11^{\text {th }}$ April, 2015 governorship polls. Similarly, Nasir el-Rufai, former Minister of FCT under Obasanjo-led PDP government, defected to APC. Aminu Bello Masari was Speaker of House of Representatives under PDP ticket, defected to APC. With the PDP's electoral statistics on the decline, observers blamed the party for shooting itself in the leg through mismanagement and poor coordination of its internal crises, inability to tame unbridled ambitions of some of its members and absence of internal democracy within the party. President Jonathan's political godfather and crony from ljaw extraction, Chief Edwin Clark had warned the party that "the imposition of candidates at all levels by the leadership would haunt the party at the polls". He stressed that "the problem in PDP across the country as of today is caused by imposition of candidates. People being replaced by those who were not qualified for reasons best known to the party. A situation whereby a governor of a state would try to nominate everybody to become part of him is not democracy" (Onabanjo, 2015).

The above factors found their bearing from 2009 when party-crises erupted in Anambra, Plateau, Bayelsa, Oyo, Ogun, Adamawa, Enugu, Edo, Lagos and Borno States. The crisis was unresolved due largely to poor party leadership, and the conflict spread to Imo, Kaduna, Akwa Ibom, Rivers with its hangover effects on other states in varying degrees. Besides, the second term ambition of President Goodluck Jonathan tore the party apart leading to the Governors' Forum - a strong political umbrella housing the state governors, breaking into two separate parts, resulting defection of seven of its members to APC. The trouble tore the party's leadership cadre and consumed its national chairmen: Solomon Lar (1998-1999); Barnabas Gemade (1999-2001); Audu Ogbeh (2001-2005); Ahmadu Ali (2005-2007); Vincent Ogbulafor (2008-2010); Okwesilieze Nwodo (2010-2010); Bamanga Tukur (2011-2014) and Adamu Muazu, (2014-2015). Gemade, Ogbeh and Nwodo joined opposition. Alhaji Abubakar Atiku, former Vice-President, joined APC. The PDP was weak and factionized at the ward, local, state and federal levels before 2015 elections (Onabanjo, 2015).

The formation of a formidable opposition political party to give fierce battle to the ruling party at the polls was good in Nigeria polity. Strong and viable opposition party balances democratic equation, and infuses new political blood into the system. Nigeria was at the verge of tilting towards one party system before the emergence of APC. The squabble within PDP and its subsequent disintegration was a healthy development in Nigeria polity, as it enthroned true democracy, promoted viable opposition and truncated unbridled political hegemony.

\section{28 March 2015 Presidential and National Assembly Elections}

The elections of 2015 was the $5^{\text {th }}$ quadrennial election to be held since the end of military rule in 1999. The presidential and national assembly elections took place on $28^{\text {th }}$ March and $11^{\text {th }}$ April for governorship and states assembly. The elections were initially postponed due to poor distribution of permanent voter cards and technical problems with the biometric card readers. The postponement was inevitable on the grounds that INEC failed to deliver PVCs to millions of voters (around 34\%). INEC disclosed that around 45.1 million registered voters out of 68.8 million had received PVCs. Further reason was a security threat that borders on the ongoing Boko Haram insurgency in some parts of three northeastern states. On $5^{\text {th }}$ February, the National Council of State (chaired by President Jonathan) informed INEC that it had launched a major decisive offensive against Boko Haram for six weeks. Therefore, due to the assets and resources that would go into this offensive, the military would be unable to provide security and logistics support for elections. Ironically, election security is the primary responsibility of the police and civil defense corps, certainly not the army who might be supportive should there be need to involve them. The speculation was whether the postponement was motivated by politics rather than security. There were doubts over political neutrality of the army and independence of INEC. Also, government closed its land and sea borders from midnight of $25^{\text {th }}$ March, 2015 until the end of the polling dates, perhaps to ward-off infiltrators and carriage of ammunitions across borders. The election was a second bid of President Jonathan and would have been his final tenure. The election was however extended to $29^{\text {th }}$ March $d u e$ to apparent delays and technical problems with the biometric card readers.

Howbeit, the ruling party vehemently objected to the use of the biometric card readers for the elections 
(particularly the presidential election) as the device would disadvantage PDP. With its technophobic disposition, PDP opposed reforming voting system, argued that the use of the technological devices would be better employed in future electoral events when the public might have been adequately sensitized on the application of the card reader. However, the strong opposition on the use of the mechanism was overruled by INEC authority as the Commission insisted that customized permanent voter cards and smart card readers would be employed to accredit all eligible registered voters before the commencement of voting proper (http://en.wikipedia.org/wiki/Nigerian_general_election,_2015). In 2015 elections, INEC revisited the electronic system of voting purposefully to curb the excesses of the political elites. With the introduction of PVCs and smart card readers, INEC seemed to have recorded unprecedented technological breakthrough in e-election administration in a developing country. The device was applied to validate the individual PVC and accredit eligible registered voters and ward-off impersonators. Although there were cases where the card readers were unable to accredit some eligible registered voters with their customized PVCs like the case of President Jonathan who the smart card reader failed to accredit. He was accredited by manual process. There was serious hiccup here and there with the biometrics card reader but the election was successfully executed.

In modern societies, one of the major elements for sustenance and development of democracy and good governance is ICT. The system is a technological evolution in a developing country like Nigeria where hitherto elections to public offices were tagged "do or die affair". It is a healthy development in a heterogeneously constituted nation, where religious sentiment, ethnic chauvinism, distrust and suspicion becloud the political scenario. Edokpayi (2015) observed that from the onset, even with the introduction of PVCs and smart card readers, it was clear, from knowledge of hindsight, that there will be some who would seek victory for their parties by any means necessary. There were bound to be flashpoints of trouble, like Rivers, Abia, and Akwa Ibom States, where crisis ensued. The most disturbing allegation was that of ballot box snatching, voter intimidation and tampering with collated figures. Some of the irregularities were enough to attract international attention. This informed why John Kerry, USA Secretary of State and his British counterpart, Philip Hammond, shared their concern as the votes were being counted "over possible political interference in some states". In a joint statement, they rightly observed that "we have seen no evidence of systemic manipulation of the process. But there are disturbing indications that the collation process - where the votes are finally counted - may be subjected to deliberate political interference" (Edokpayi, 2015).

Before the 28th March, 2015 elections, the PDP membership in the House had dropped to 162 as against APC's 179 , thus putting PDP in the minority. In the new dispensation, PDP has 45 senators and APC has 64 senators in the 109-member chamber. Similarly, in the House of Representatives, PDP is also in minority with 125 lawmakers as against APC's 225, and other parties 10 seats of the 360-member chamber. The presidential election results indicated that APC garnered $15,424,921$ votes or $53.96 \%$ and PDP secured $12,853,162$ votes or $44.96 \%$. The APC flag-bearer was declared the President of Federal Republic of Nigeria with effect from 29th May, 2015. This is in consonance with the provision of Article 134(2) of the 1999 Constitution of the Federal Republic of Nigeria (as amended) which stipulates that:

a candidate for an election to the office of President shall be deemed to have been duly elected where, there being more than two candidates for the election - (a) he has the highest number of votes cast at the election; and (b) he has not less than one-quarter of the votes cast at the election in each of at least two-thirds of all the States in the Federation and the Federal Capital Territory, Abuja (FRN, 1999).

President Goodluck Jonathan conceded defeat on $31^{\text {st }}$ March, 2015 barely before the presidential election result was announced. The detailed results on APC and PDP with the number of registered voters and percentage of PVCs distributed in south-east states are illustrated hereunder.

Table 3: 2015 Presidential election results from south east zone

\begin{tabular}{|l|c|c|c|c|c|c|}
\hline States & Number of Registered Voters & Percentage of PVCs Distributed & \multicolumn{2}{|c|}{ All Progressive Congress } & \multicolumn{2}{|c|}{ Peoples Democratic Party } \\
\cline { 4 - 7 } & & $(\%)$ & APC Votes & $(\%)$ & PDP Votes & $(\%)$ \\
\hline Abia & $1,396,162$ & 84,34 & 13,394 & 3.51 & 368,303 & 96.49 \\
\hline Anambra & $1,963,173$ & 84.50 & 17,926 & 2.64 & 660,762 & 97.36 \\
\hline Ebonyi & $1,074,273$ & 78.97 & 19,518 & 6.96 & 323,653 & 93.04 \\
\hline Enugu & $1,429,221$ & 85.61 & 14,157 & 3.95 & 553,003 & 96.48 \\
\hline Imo & $1,803,030$ & 94.70 & 133,253 & 19.24 & 559,185 & 80.76 \\
\hline
\end{tabular}

Source: Independent National Electoral Commission 
The table 3 above indicated that the number of registered voters in each south-east states is in disparity with the accredited voters as the figures of registered voters are outrageously higher than the accredited voters turnout. Even though some eligible voters were disenfranchised by the biometric card readers, the registered voters list in each state was astronomically higher. The aim of applying technological devices for revalidation of voters register to eliminate multiple registration of voters, including fictitious voters' names in the exercise seemed to have been compromised by this bloated number of registered voters. No state received 100\% of the PVCs, evidently some electorates were shortchanged in the exercise. This might have given room for excess permanent voter cards being located in wrong hands. However, other presidential candidates and parties' presidential results are shown in comprehensive table 4 below and further illustrated in figure 2 .

Table 4: 2015 Comprehensive Report of Presidential Election Results

\begin{tabular}{|c|l|l|c|c|}
\hline S/No & Presidential Candidate & Political Party & Vote & $\%$ \\
\hline 1. & Muhammadu Buhari & All Progressives Congress & $15,424,921$ & 53.96 \\
\hline 2. & Goodluck Jonathan & Peoples Democratic Party & $12,853,162$ & 44.96 \\
\hline 3. & Adebayo Ayeni & African People's Alliance & 53,537 & 0.19 \\
\hline 4. & Ganiyu Galadima & Allied Congress Party of Nigeria & 40,311 & 0.14 \\
\hline 5. & Sam Eke & Citizens Popular Party & 36,300 & 0.13 \\
\hline 6. & Rufus Salau & Alliance for Democracy & 30,673 & 0.11 \\
\hline 7. & Mani Ahmad & African Democratic Congress & 29,665 & 0.11 \\
\hline 8. & Allagoa Chinedu & Peoples Party of Nigeria & 24,475 & 0.09 \\
\hline 9. & Martin Onovo & National Conscience Party & 24,455 & 0.09 \\
\hline 10. & Tunde Anifowose-Kelani & Accord Alliance & 22,125 & 0.08 \\
\hline 11. & Chekwas Okorie & United Progressive Party & 18,220 & 0.06 \\
\hline 12. & Comfort Sanawa & KOWA Party & 13,076 & 0.05 \\
\hline 13. & Godson Okoye & United Democratic Party & 9,208 & 0.03 \\
\hline 14. & Ambrose Albert Owuru & Hope Party & 7,435 & 0.03 \\
\hline Invalid Blank Votes & & $\mathbf{8 4 4 , 5 1 9}$ & - \\
Total Vote Cast & & $\mathbf{2 9 , 4 3 2 , 0 8 3}$ & 100 \\
Registered Voters Turnout & $\mathbf{6 7 , 4 2 2 , 0 0 5}$ & 43.65 \\
\hline
\end{tabular}

Source: Independent National Electoral Commission

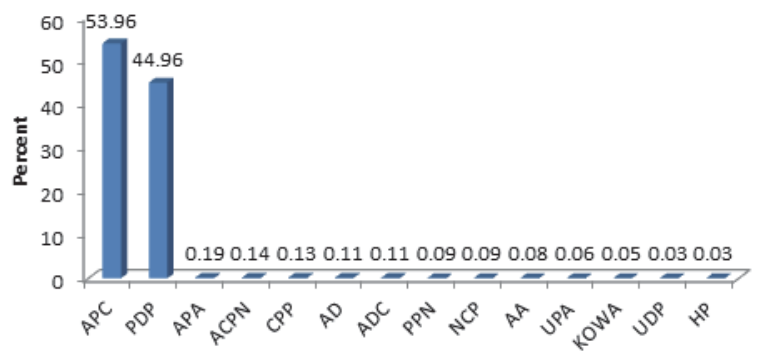

Figure 2: Graphic Illustration of Party Performance in the Presidential Election

Table 4 above shows that the vote margin between APC and PDP was 2,571,759. It also indicates that there was no other strong opposition to PDP in the election except the APC (see figure 2). Prior to the merger of the four political parties to form APC, the parties were individually in the category of bracket 3-14 mushroom parties in table 4. The table indicates that 844,519 votes were invalid excluding invalid votes for national assembly, governors and states house of assembly elections. The figure illustrates the level of political underdevelopment of Nigeria. The total votes cast were $29,432,083$, while registered voters turnout was $67,422,005$ or $43.65 \%$. This also depicts lower percentage of voters turnout in 2015 presidential election than the previous elections where voters turnout in 1999 was 52\%, 2003 (69\%), 2007 (57\%), and 2011 (54\%) (see figure 3). This shows that 37,989,922 registered eligible voters were perhaps disenfranchised as record shows that the voters actually turned out to cast their votes. The voters turnout of $43.65 \%$ in the presidential election in 2015 was below average compared to the previous elections from 1999. 


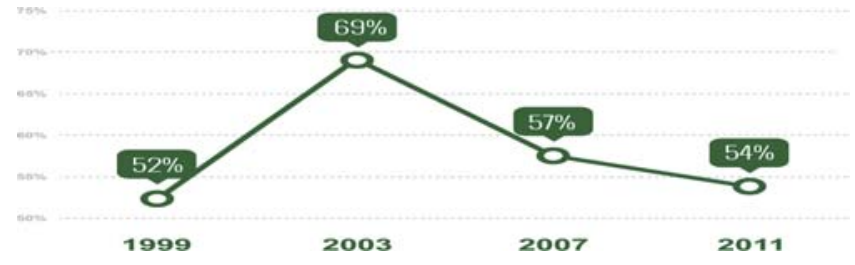

Figure 3: Nigeria Presidential Election Turnout, 1999 - 2011

Source: Independent National Electoral Commission

The registered voters turnout in the aggregate since 1999 has been in the average of 55.13\% which expressed low political participation amongst the electorates in comparison to selected African countries. For example, in 2011, the voters turnout was $54 \%$ which was equal to Zambia (54\%) in the same year. Registered voters turnout in Kenya in 2013 was $86 \%$ in spite of its turbulent election and post-election violence, followed by Ghana with $80 \%$ in 2012 , South Africa (77\%) in 2009, Cameroon (68\%) in 2011, and Senegal (57\%) in 2012 (see figure 4). In contrast, the 43.65\% voters turnout in 2015 presidential election showed some degree of political apathy amongst the electorates. South African political consciousness is overwhelming considering the trauma of apartheid system which the country experienced in the hands of minority white. The registered voter turnouts in these African states demonstrate the level of political consciousness in the continent, despite the challenges confronting African nations in contemporary democracy.

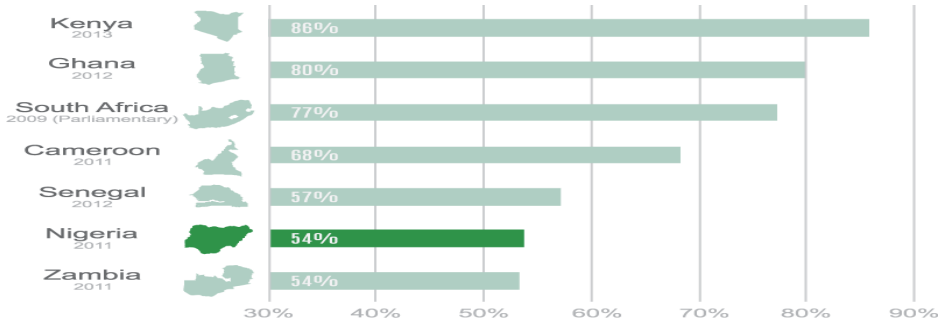

Figure 4: Selected African Countries on Presidential Election Turnout

Source: International Institute for Democracy and Electoral Assistance

\section{2015 Governorship Election}

The gubernatorial elections on $11^{\text {th }}$ April, 2015 were marred by violence in some states. The flashpoint areas were Rivers, Akwa Ibom, Abia and Taraba States, including some polling units in various locations. The results show that APC candidates won the governorship race in 20 states, while the PDP candidates won in 9 out of the 29 states that were due for April 2015 elections.

An independent election monitoring group, the African Centre for Leadership, Strategy and Development (ACLSD), disclosed that the Rivers State elections were bloody, crooked and unacceptable anywhere. The body described the elections as "a far cry from what elections should be", claiming that what happened in the state did not meet the accepted international standards of electioneering, including the ones set by the INEC. The Coordinator of ACLSD, Mr. Humphrey Bekaren observed that there were deliberate delays and diversion of election materials, and other electoral irregularities. Election in Emohua Local Government Area of Rivers State was cancelled by the INEC following official report that the election was marred by violence. In the same manner, the Returning Officer in Jigawa State gave the total number of registered voters as $1,819,773$, out of which $1,217,504$ voters were accredited for election. The Returning Officer disclosed that 26,977 votes were declared void in the 27 local government areas of the State. In Delta State, there were 2,044,372 registered voters, while 1,017,796 voters were accredited and. 24,913 votes were invalid. In Taraba State, the Returning Officer stated that the number of cancelled votes 127,125 was higher than the margin between the winner - PDP candidate and the runner up - APC candidate which is 54,812 votes. In the final result released by INEC, PDP was leading with 317,198 votes, while the APC got 262,386 votes. INEC ordered for a rerun 
election on the affected areas - Donga and Bali Local Government Areas. The PDP finally won the rerun election with 360,318 votes, while APC got 275,985 votes.

\section{Methodology}

The researcher adopted a survey research design to elicit information from the electorates on the performance of INEC in administering the election using biometric card reader and the customized permanent voter card, to ascertain whether the technological devices minimized electoral malpractices and enthroned free, fair, and credible election in 2015 general election. Given that Survey research is a systematic method for studying behaviour that cannot be observed or experimented on directly (McNabb, 2004). The instrument used to glean information from the respondents was questionnaire. In this light, Alford (2011) noted that research design is measurement process that involves asking questions of respondents and collecting information from a small number of people to be representative of a larger number of people. The quantitative method of analysis was employed with empirical verifications. Qualitative method of data collection was also used to glean data from documentary evidence of secondary sources, as qualitative studies can also be added to quantitative ones, to gain a better understanding of the meaning and implications of the findings, as more creative combinations are seen in triangulation (Miles and Huberman, 1994). The area of the study is South-East comprising five states. The population of the study is $7,665,859$ registered voters, the Study adopted Yamane statistical formula to determine the sampled population as presented below:

\subsection{Sampling Techniques}

Yamane's Statistical Formula was used to determine the sample size of the study. This decision was informed by the high level ability/capacity of the formula to control sampling error.

$$
\begin{aligned}
& \text { Yamane (1973:727-728) stated the formula thus: }
\end{aligned}
$$

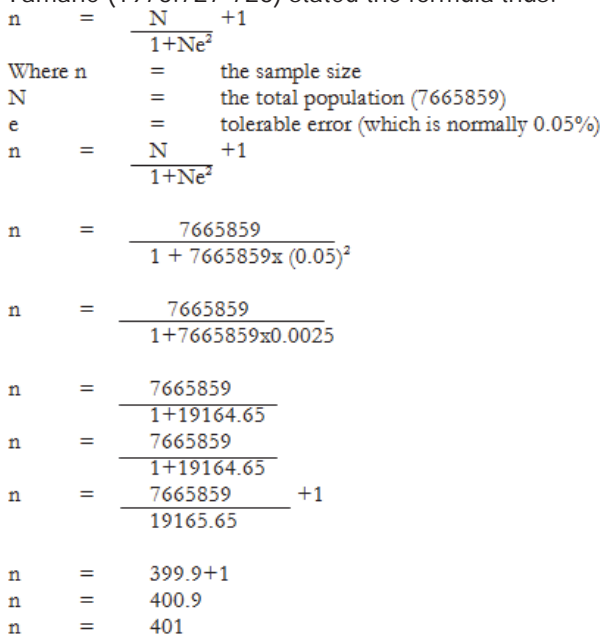

Based on the above calculation, sample size was 401. The distribution of the questionnaire across the South Eastern States was based on the percentage derived from the registered voter per state. Below is the tabular representation.

Table 5: Questionnaire Distribution and Retrieval

\begin{tabular}{|l|c|c|c|c|}
\hline States & Registered Voters & Percentage by Registered voters & Distributed by derived percentage & Retrieved Questionnaire \\
\hline Abia & $1,396,162$ & $18.3 \%$ & 74 & 72 \\
\hline Anambra & $1,963,173$ & $25.6 \%$ & 103 & 99 \\
\hline Ebonyi & $1,074,273$ & $14 \%$ & 56 & 56 \\
\hline Enugu & $1,429,221$ & $18.7 \%$ & 74 & 74 \\
\hline Imo & $1,803,030$ & $23.53 \%$ & 94 & 93 \\
\hline Total & $\mathbf{7 , 6 6 5 , 8 5 9}$ & 100 & 401 & 394 \\
\hline
\end{tabular}

Source: Computed by the Researcher. 
The percentage on the third column was derived by dividing the registered voters of each state with the total registered voters in the South East Nigeria, after the division, one hundred (100) was used to multiply the outcome, out of which 401 distributed, 394 respondents returned their completed questionnaires. The researcher posed the following questions (1) "Does the introduction of ICT to election administration in Nigeria minimize electoral fraud in 2015 election?" (2) "Does INEC face challenges in the e-administration of 2015 elections?" The hypotheses were thus: (1) "Introduction of ICT to 2015 election administration in Nigeria minimized electoral fraud"; (2) "INEC faced challenges in the e-administration of 2015 elections".

\section{Analysis}

This section analyzed the data gathered from the survey to establish whether the introduction of ICT to election administration in Nigeria minimized electoral malpractices in 2015 elections. It also ascertained whether INEC faced challenges in the exercise. The analysis is based on the 394 duly completed questionnaires retrieved from respondents out of the 401 copies administered.

Table 6: Gender

\begin{tabular}{|c|c|c|}
\hline Respondents & Frequency & Percent \\
\hline Male & 250 & $62.34^{`}$ \\
\hline Female & 151 & 37.66 \\
\hline Total & 401 & 100.0 \\
\hline
\end{tabular}

The table above shows that male respondents were higher than the female with $64.9 \%$ while the female respondents were less with $35.1 \%$.

Table 7: Educational Qualification

\begin{tabular}{|c|c|c|}
\hline & Frequency & Percent \\
\hline FSLC & 18 & 4.5 \\
\hline WASC & 201 & 50.1 \\
\hline ACE/NCE/HND & 35 & 8.7 \\
\hline B.Sc/B.Ed/BA & 85 & 21.2 \\
\hline M.Sc/M.Ed/MA & 55 & 13.7 \\
\hline Ph.D/D.Sc & 7 & 1.7 \\
\hline Total & 401 & 100 \\
\hline
\end{tabular}

The above table illustrates that WASC holders are in majority of the respondents with $50.1 \%$. First degree holders recorded $21.2 \%$, while masters degree holders recorded $13.7 \%$. The third in the table is the ACE/NCE/HND holders with $8.7 \%$, while FSLC recorded $4.5 \%$. The least is Ph.D/D.Sc. holders with $1.7 \%$. This indicates that the respondents are literate to understand the variables in the questionnaire.

Table 8: Preliminary Interogation

\begin{tabular}{llll}
\hline S/N & Item & Yes & $\%$ No \\
\hline 1. & Are you a registered voter for 2015 general election? & 79.7 & 20.3 \\
2. & Did you have your PVC for 2015 elections? & 66.4 & 33.6 \\
3. & Were you accredited with the biometric card reader? & 50.1 & 49.9 \\
4. & If 'No' in No. 3 above, were you eventually accredited by manual process? & 29.0 & 71.0 \\
$\mathbf{5 .}$ & Did you cast your vote? & 57.5 & 42.5 \\
\hline
\end{tabular}

Table7 shows that $79.7 \%$ of the respondents registered for 2015 elections, while $20.3 \%$ did not register. $66.4 \%$ collected their permanent voter cards while $33.6 \%$ did not receive the card. The table also illustrates that $50.1 \%$ accredited with the biometric card reader, while $49.9 \%$ did not. On No.4 item in the table, $29 \%$ of the respondents eventually accredited by manual process while $71 \%$ did not. $57.5 \%$ cast their votes but $42.5 \%$ was disenfranchised. Apparently, there was no equity and inclusion mechanism in the electoral process. 
Table 9: Level of agreement of respondents on the statement that introduction of ICT to election administration in Nigeria minimized electoral malpractices in 2015 general elections

\begin{tabular}{llcccccc}
\hline S/N & Item & \%SA & \%A & \%D & \%SD Mean & SD \\
\hline $\mathbf{1}$ & PVC in 2015 election reduced multiple voting & 41.4 & 35.4 & 10.2 & 13.0 & 3.05 & 1.017 \\
2 & The biometric card reader eliminated multiple registration in 2015 election & 31.4 & 46.4 & 9.9 & 12.2 & 2.97 & 0.95 \\
$\mathbf{3}$ & The biometric card reader disenfranchised many eligible voters & 39.8 & 40.0 & 7.5 & 12.7 & 3.07 & 0.988 \\
$\mathbf{4}$ & The INEC officials were not adequately educated on how to use the smart card reader & 32.2 & 43.4 & 7.8 & 16.6 & 2.91 & 1.028 \\
$\mathbf{5}$ & The biometric card reader developed serious technical problems that adversely affected & 53.3 & 38.3 & 3.2 & 5.1 & 3.4 & 0.782 \\
& accreditation exercise & & & & & & \\
$\mathbf{6}$ & The election was rigged even with smart card reader & 49.4 & 36.2 & 4.5 & 9.9 & 3.25 & 0.936 \\
$\mathbf{7}$ & There was difficulty in collection of PVCs & 50.0 & 38.4 & 5.4 & 5.1 & 3.34 & 0.802 \\
$\mathbf{8}$ & Electorates were not adequately sensitized on how the card reader device functions & 34.4 & 42.0 & 8.8 & 14.8 & 2.96 & 1.012 \\
$\mathbf{9}$ & Even with the card reader, the number of registered voters was inflated & 32.6 & 43.3 & 11.4 & 12.8 & 2.96 & 0.975 \\
$\mathbf{1 0}$ & The voters register was published for online verification & 15.9 & 30.5 & 26.2 & 27.3 & 2.35 & 1.046 \\
$\mathbf{1 1}$ & The biometric card reader should not be used for future elections in Nigeria & 21.8 & 19.3 & 30.2 & 28.8 & 2.34 & 1.112 \\
\hline
\end{tabular}

The above table illustrates that the PVC reduced multiple voting in 2015 election, while the biometric card-reader eliminated multiple registration. The respondents agreed that the biometric card reader disenfranchised many eligible registered voters. The responses depict that INEC officials were not adequately trained on how to use the devices. This lapse compounded the problems encountered by INEC personnel. The respondents also agreed that the biometric card reader developed serious technical problems that adversely affected accreditation. Many eligible voters were subsequently disenfranchised. It was affirmed in table 8 above that the election was rigged even with smart card reader; there was difficulty in collection of PVCs by electorates in most states; electorates were not adequately sensitized on how the card reader functions; even with the card reader, the number of registered voters was inflated. The respondents disagreed that the voters register was published online for verification; The application of ICT concept was considered necessary for future elections in Nigeria

Table 10: Level of agreement of respondents on the statement that INEC encountered challenges in the e-administration of 2015 general elections

\begin{tabular}{llcccccc}
\hline S/N & Item & \%SA & \%A & \%D & \%SD & Mean & SD \\
\hline $\mathbf{1}$ & Manual voting took place in all polling units & 43.8 & 46.0 & 3.1 & 7.0 & 3.27 & 0.825 \\
$\mathbf{2}$ & Ad hoc staff deployed by INEC facilitated rigging & 31.2 & 44.4 & 7.8 & 16.6 & 2.9 & 1.022 \\
$\mathbf{3}$ & Under-aged voted in some states & 62.0 & 30.8 & 1.9 & 5.3 & 3.49 & 0.78 \\
$\mathbf{4}$ & Ballot boxes were snatched from polling units & 27.8 & 41.9 & 9.8 & 20.5 & 2.77 & 1.071 \\
$\mathbf{5}$ & Non-indigenes were not allowed to collect PVCs in some states & 36.1 & 36.2 & 11.1 & 16.6 & 2.92 & 1.064 \\
$\mathbf{6}$ & INEC officials compromised their statutory function, aided and abated rigging & 27.7 & 48.7 & 7.6 & 16.0 & 2.88 & 0.99 \\
$\mathbf{7}$ & Law enforcement agents were deployed to aid in rigging and intimidating supporters of & 26.2 & 32.0 & 14.0 & 27.8 & 2.57 & 1.152 \\
& opponents & & & & & & \\
$\mathbf{8}$ & Money was used to influence voting behavior & 52.3 & 37.3 & 4.4 & 6.1 & 3.36 & 0.826 \\
$\mathbf{9}$ & Elections were disrupted in some polling units & 43.0 & 50.5 & 3.3 & 3.3 & 3.33 & 0.696 \\
$\mathbf{1 0}$ & INEC was partisan in the distribution of the PVC and other election materials & 34.6 & 47.4 & 6.5 & 16.5 & 2.95 & 1.035 \\
$\mathbf{1 1}$ & Thugs were deployed by politicians to disrupt the elections & 29.5 & 46.4 & 8.7 & 15.4 & 2.9 & 0.994 \\
$\mathbf{1 2}$ & Mass exodus of non-indigenes from the North because of fear of post-election violence & 56.9 & 29.1 & 7.2 & 6.9 & 3.36 & 0.888 \\
& had serious negative effect on the election results & & & & & & \\
$\mathbf{1 3}$ & Foreigners were recruited to vote & 23.1 & 26.6 & 17.3 & 32.9 & 2.4 & 1.168 \\
$\mathbf{1 4}$ & INEC general performance in the elections was Excellent & 11.5 & 34.5 & 25.8 & 28.1 & 2.29 & 1.001 \\
$\mathbf{1 5}$ & Nigeria is not yet developed for e-administration of elections & 36.3 & 24.5 & 17.6 & 21.7 & 2.75 & 1.16 \\
\hline
\end{tabular}

Item No. 1 in the above table affirms that manual voting took place in all polling units. This encourages rigging. Respondents agreed that INEC ad hoc staff facilitated rigging, while under-aged voted in some states. The table shows that the respondents agreed that ballot boxes were snatched from some polling units; non-indigenes were not allowed to collect their PVCs in some states; INEC officials compromised their statutory functions which aided and abated rigging; law enforcement agents were deployed to intimidate and aid in rigging; money was used to influence voters behavior; elections were disrupted in some polling units by party-thugs; INEC was adjudged to be partisan in the distribution of PVC and other election materials; respondents agreed that pre-election mass-exodus of non-indigenes in the North for fear of 
post-election violence, affected election results adversely; but respondents disagreed that foreigners were recruited to vote. The respondents disagreed also that INEC performance in the elections was excellent. Respondents affirmed that Nigeria is not developed for e-administration of elections.

\section{Discussion on Findings}

The study revealed in table 7 that $79.7 \%$ registered for 2015 election, while $20.3 \%$ did not register. $66.4 \%$ received the PVCs, 33.6\% did not receive and was disenfranchised. 50.1\% of the respondents was accredited with the biometric card reader, while $49.9 \%$ was not accredited. $29 \%$ was later accredited manually, while $71 \%$ was disenfranchised. $57.5 \%$ cast their votes while $42.5 \%$ was disenfranchised. This result supports the fear of some stakeholders that, at its level of technological development, Nigeria was pre-matured to apply such sophisticated technological devices in election administration.

In table 8, the study showed that PVC reduced multiple voting, biometric card reader eliminated multiple registration. It was revealed that the biometric card reader disenfranchised many eligible registered voters because the technological device developed technical problems and voting was extended to the following day. Besides, the INEC officials were not thoroughly trained on how to use the smart card reader. The study also indicated that election was rigged even with the smart card reader; and electorates encountered difficulties in collecting the PVCs and many registered eligible voters were disenfranchised because they could not receive their PVC. The apparent confusion on the part of the electorates was because they were not adequately sensitized on how the card reader device functions. In spite of its use, the number of registered voters was inflated, which facilitated rigging. No voter register was published online for verification. However, the respondents supported the use of biometric card reader for future elections. Evidently, there were many flaws in the management techniques. Howbeit, in all, the rate of electoral fraud was minimized to its barest minimum. This checkmated post-election violence.

The analysis shows that, in spite of its shortcomings, the use of ICT in election administration minimized the degree of electoral fraud in 2015. It is essential to consolidate and improve on INEC performance in future. This validates the first hypothesis that "introduction of ICT to 2015 elections administration minimized electoral fraud".

Table 9 indicates that INEC encountered numerous challenges. The study revealed that manual voting took place in all polling units and the INEC ad hoc staff facilitated rigging; under-aged voted in some states. In some polling units, ballot boxes were snatched by thugs, while non-indigenes were denied PVCs in some states. It was revealed in the study that some INEC officials compromised their statutory functions. The study also reveals that law enforcement agents intimidated voters and aided rigging; while money was used to influence voters behaviour. It was revealed that election was disrupted in some polling units; INEC was partisan in the distribution of the PVCs and other election materials. Also mass exodus of non-indigenes from the North adversely affected election results as they were disenfranchised. No foreigner was recruited to vote in the election as the study revealed, but INEC performance in the election was not satisfactory. It was acknowledged that Nigeria was not yet developed for e-administration of elections. In table 8, respondents supported the use of biometric card reader for future elections.

The analysis above reveals that INEC faced numerous challenges in administering the elections. This validates the second hypothesis that "INEC encountered challenges in the election management".

\section{Conclusion}

Conduct of free, fair and credible election has been the perennial problem in Nigeria. Although INEC performance in 2015 elections was not satisfactory, it had been adjudged acceptable by international communities. This is so because the United Nations Secretary-General, Ban Ki-Moon had congratulated citizens and government of Nigeria for conducting peaceful and orderly election. Besides, AU-EOM agreed that the elections were conducted in a peaceful atmosphere and met the continental and regional principles of democratic elections. ECOWAS-EOM also said that the election met the criteria of being free and transparent, despite pockets of ugly incidents and logistical challenges. The Commonwealth Election Observer Missions (CW-EOM) described the conduct as generally peaceful and transparent. None of the external observers indicated that the election was credible. Emphasis was on peacefulness and orderliness. Election might be peaceful and orderly in outlook but marred with hidden irregularities.

Considering political instability in Nigeria since 1922, post-colonial electoral problems and other ugly electoral experiences like incidents of wanton violence that characterized all past elections, the application of ICT stemmed electoral vices, minimized fraud and somewhat increased credibility in the elections. Although there were hiccups here and there as acknowledged by the external observers due to the fact that the biometric card reader and other 
technological gadgets were still at their experimental stages. The e-administration in election management was seemingly its first kind in Africa. Therefore, it is difficult to carry out such huge experiment in a developing country without some flaws. The challenges experienced by INEC in executing the project were inevitable looking at where Nigerians started their political journey. It has built a springboard through which platform the country would consolidate its achievements and make concerted effort to improve on the gains in future exercises. The political class with its instinct to always win elections at all costs and by all means, would definitely be the cog in the wheel of political development in Nigeria.

\section{References}

Alford. H. (2011). Designing and Conducting Survey Research. [Online] Available: http://www.smc.edu/EnrollmentDevelopment/InstitutionalResearch/Documents/Staff_Development_Resources/Designing\%20and \%20Conducting\%20Survey\%20Research.pdf (February 24, 2016)

Edokpayi, B. (2015). Action items for the president-elect. Tell Magazine, 16:10.

Group advocates ict deployment for electoral process management [Online] Available: http://www.channelsty.com/2014/03/04/group-advocates-ict-deployment-for-elecoral-process-management/ (April 2, 2015).

Hague, R. \& Harrop, M. (2010). Comparative government and politics: An introduction. United Kingdom: Palgrave Macmillan.

Heywood, A. (2002). Politics. New York: Palgrave Macmillan.

Jega, A. (2012). Independent national electoral commission (INEC) strategic plan, 2012-2016. Abuja: Government Press.

Johari, J. C. (2009). Principles of modern political science. New Delhi: Sterling Publishers Private Limited.

McNabb, D. E. (2004). Research methods for political science. New York: M. E. Sharpe.

Miles, M.B. and Huberman, A. M. (1994), Qualitative Data Analysis: an expanded sourcebook. Thousand Oaks: Sage.

Nwagwu, E. J. (2011). Elections and party politics in Nigeria: Lesson after fifty years.

Nigeria at Fifty: Issues, Challenges and Agenda. Vol. 2. Enugu: Timex Entreprises.

Nweke, Remmy, (2008), ICT and elections in Africa: Nigeria as case study. [Online] Available: http://www.itrealms.com.ng/2008/04/ictand-elections-in-africa-nigeria-as.html (April 28, 2015)

Nigerian general election, 2015 [Online] Available: http://en.wikipedia.org/wiki/Nigerian_general_election_2015 (April 27, 2015)

Ocholi, D. (2015). Will Jega survive? Verbatim News Magazine, March 23:11

Onabanjo, D. (2015). PDP: Challenges and lessons of a fall. Tell Magazine, April 20:14

Yamane, T. (1973), Statistics: An Introductory Analysis. New York: Harper and Row Publishers Inc. 